\title{
Percutaneous mitral commissurotomy for patient with dual chamber pacemaker
}

Przezskórna komisurotomia u chorej po wszczepieniu dwujamowego układu stymulującego serce

\section{Zbigniew Chmielak', Witold Rużyłło ${ }^{1}$, Sylwia Kołodziejczyk², Andrzej Januszewicz², Adam Witkowski}

1Samodzielna Pracownia Hemodynamiki, Instytut Kardiologii, Warszawa

2Klinika Nadciśnienia Tętniczego, Instytut Kardiologii, Warszawa

Post Kardiol Interw 2010; 6, 4 (22): 211-214 DOI: $10.5114 /$ pwki.2010.17637

\begin{abstract}
Percutaneous mitral commissurotomy is a method of choice for selected patients with symptomatic mitral valve stenosis. However in patients with dual chamber pacemaker this procedure is much more difficult to perform because of two pacemaker leads present in the right atrium. We present a case of a 60 -year-old female with dual chamber pacemaker who underwent successful percutaneous mitral commissurotomy.
\end{abstract}

Key words: mitral valve stenosis, percutaneous mitral commissurotomy, dual chamber pacemaker

Streszczenie

Przezskórna komisurotomia mitralna jest metodą z wyboru w leczeniu wybranych chorych z objawowym zwężeniem zastawki dwudzielnej. Zabieg jest jednak znacznie trudniejszy u chorych z wszczepionym dwujamowym układem stymulującym. Jest to spowodowane obecnością dwóch elektrod w prawym przedsionku. Przedstawiamy przypadek 60-letniej chorej po wszczepieniu dwujamowego układu stymulującego, u której wykonano przezskórną komisurotomię mitralną.

Słowa kluczowe: zwężenie zastawki mitralnej, przezskórna komisurotomia mitralna, dwujamowy układ stymulujacy

\section{Opis przypadku}

Kobieta 60-letnia została przyjęta do Instytutu Kardiologii w trybie dyżurowym z powodu kolejnego napadu migotania przedsionków w okresie kilku dni. Od 3 lat chora zgłaszała ograniczenie tolerancji wysiłku fizycznego (II klasa czynnościowa wg NYHA) oraz napadowe migotanie przedsionków. Ostatni napad rozpoczą się ok. 4 godz. przed przyjęciem do Instytutu Kardiologii. Przed kilkunastoma miesiącami w innym ośrodku z powodu licznych epizodów bradykardii zatokowej i konieczności intensyfikacji leczenia antyarytmicznego chorej wszczepiono dwujamowy układ stymulujący serce typu DDD. Rozpoznano wówczas wadę zastawki mitralnej i wadę zastawki aortalnej. Uznano jednak, że obie wady są nieistotne hemodynamicznie i chora została zakwalifikowana do leczenia zachowawczego. Wykonano również koronarografię, która nie wykazała istotnych zmian miażdżycowych w tętnicach wieńcowych.
Przy przyjęciu do Instytutu Kardiologii chora była w stanie ogólnym dobrym, czynność serca całkowicie niemiarowa, z czynnością komór 100-120/min, ciśnienie tętnicze wynosiło 110/75 mm Hg. Po uzupełnieniu stężenia elektrolitów i włączeniu dodatkowo amiodaronu (chora dotychczas była leczona bisoprololem) uzyskano powrót rytmu zatokowego.

W przezklatkowym badaniu echokardiograficznym wykonanym po przywróceniu rytmu zatokowego stwierdzono istotne zwężenie oraz nieistotną hemodynamicznie niedomykalność zastawki mitralnej. Pole powierzchni zastawki dwudzielnej mierzone metodą Dopplera na podstawie czasu póttrwania gradientu ciśnień wynosiło $1,3 \mathrm{~cm}^{2}$. Maksymalny gradient mitralny wynosił $19 \mathrm{~mm} \mathrm{Hg}$, a średni $10 \mathrm{~mm} \mathrm{Hg}$. Płatki zastawki mitralnej były zwłókniałe, tylny płatek praktycznie nieruchomy, natomiast ruchomość płatka przedniego nieznacznie upośledzona.

Adres do korespondencji/Corresponding author:

dr hab. n. med. Zbigniew Chmielak, Samodzielna Pracownia Hemodynamiki, Instytut Kardiologii, ul. Alpejska 42, 04-628 Warszawa,

tel.: +48 2281540 14, e-mail: zchmielak@ikard.pl

Praca wpłynęła 8.06.2010, przyjęta do druku 15.06.2010. 


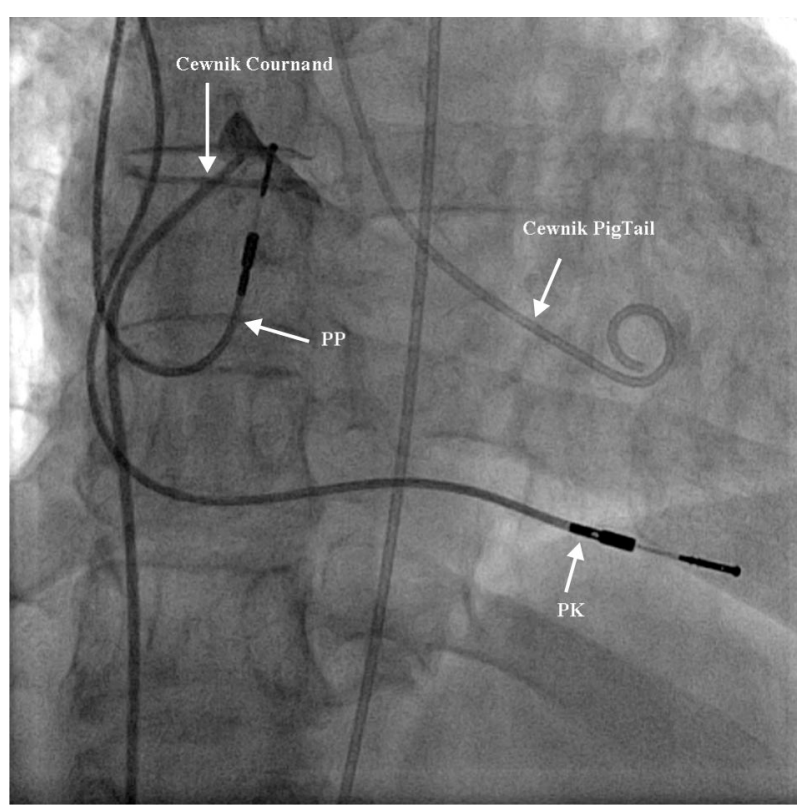

Ryc. 1. Widoczne dwie elektrody stymulujące: PP - elektroda wszczepiona do prawego przedsionka, PK - elektroda wszczepiona do prawej komory serca. Wstrzyknięty przez cewnik Cournanda kontrast pokazuje przegrodę międzyprzedsionkową

Fig. 1. Picture shows two pacemaker leads: $P P$ - pacemaker lead implanted into the right atrium, $P K$ - pacemaker lead implanted into the right ventricle. Contrast injection via Cournand catheter shows interatrial septum

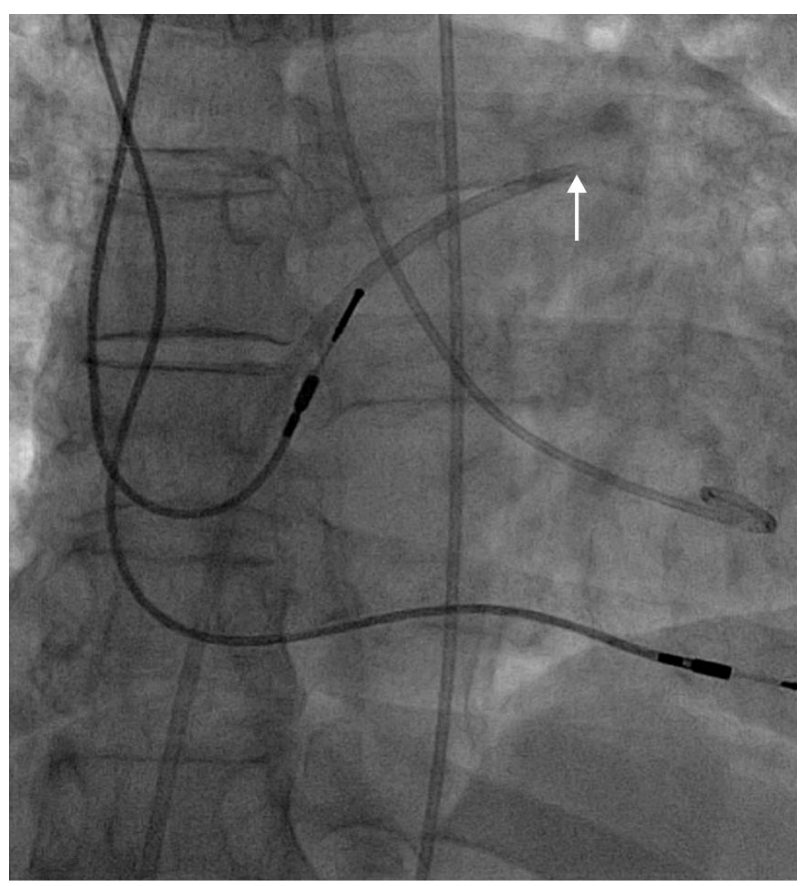

Ryc. 2. Widoczny w lewym przedsionku cewnik Moulinsa (strzałka)

Fig. 2. Moulins catheter in the left atrium (arrow)
Ponadto stwierdzono drobne zwapnienie centralne na brzegu płatka przedniego oraz skrócenie nici ścięgnistych. Dodatkowo odnotowano nieistotne hemodynamicznie zwężenie i niedomykalność zastawki aortalnej (maksymalny gradient aortalny $28 \mathrm{~mm} \mathrm{Hg}$, średni $13 \mathrm{~mm} \mathrm{Hg}$ ) oraz umiarkowaną niedomykalność zastawki trójdzielnej. W przezprzełykowym badaniu echokardiograficznym wykluczono obecność materiału zatorowego w lewym przedsionku i jego uszku. Badanie radiologiczne klatki piersiowej wykazało umiarkowane cechy zastoju w krążeniu płucnym.

Z uwagi na istotne zwężenie zastawki dwudzielnej z towarzyszącymi cechami niewydolności serca ustalono, że chora wymaga leczenia interwencyjnego. Rozpatrywano wykonanie przezskórnej komisurotomii mitralnej oraz leczenie kardiochirurgiczne - plastykę zastawki lub operację wymiany zastawki. Ostatecznie z uwagi na niewielki stopień uszkodzenia kompleksu mitralnego oraz wspóttowarzyszącą wadę zastawki aortalnej i trójdzielnej, których w chwili obecnej nie uznano za istotne hemodynamicznie, chora została zakwalifikowana do przezskórnej komisurotomii mitralnej.

\section{Opis zabiegu przezskórnej komisurotomii mitralnej}

Zabieg wykonano w Samodzielnej Pracowni Hemodynamiki Instytutu Kardiologii. Z nakłucia żyły udowej, przy użyciu cewnika Cournanda wykonano diagnostyczne cewnikowanie prawego serca (ryc. 1.). Następnie z dostępu od tętnicy udowej wykonano cewnikowanie lewego serca i wentrykulografię lewej komory. Jednoczesny zapis ciśnień w kapilarach i w lewej komorze pokazał, że średni gradient mitralny wynosił $10 \mathrm{~mm} \mathrm{Hg}$. Następnie pod kontrolą RTG nakłuto przegrodę międzyprzedsionkową igłą Brockenbrougha, po której do lewego przedsionka wprowadzono cewnik Mullinsa (ryc. 2.). Po podaniu heparyny niefrakcjonowanej założono do lewego przedsionka prowadnik, po którym wprowadzono balon Inoue 28 (ryc. 3. i 4.). Wszystkie manipulacje cewnikiem Cournanda oraz igłą do nakłucia przegrody wykonywano z ogromną ostrożnością, aby nie przemieścić żadnej z elektrod.

Balon Inoue wypełniono w zastawce mitralnej jeden raz, do średnicy $26 \mathrm{~mm}$. Jednoczesny pomiar ciśnień w lewej komorze i w lewym przedsionku przeprowadzony po poszerzeniu zastawki balonem 26-milimetrowym wykazał spadek średniego gradientu mitralnego do $5 \mathrm{~mm} \mathrm{Hg}$. Badanie echokardiograficzne, wykonane w pracowni hemodynamicznej w celu oceny skuteczności bezpośredniej zabiegu, wykazało pełne rozdzielenie spoideł. Procedurę uznano zatem za skuteczną i zakończono. Prawdopodobnie przyczyną resztkowego gradientu mitralnego była sztywność płatków zastawki i zmiany w aparacie podzastawkowym. Chora wróciła na oddział i została wypisana do domu w 2. dobie po zabiegu. 


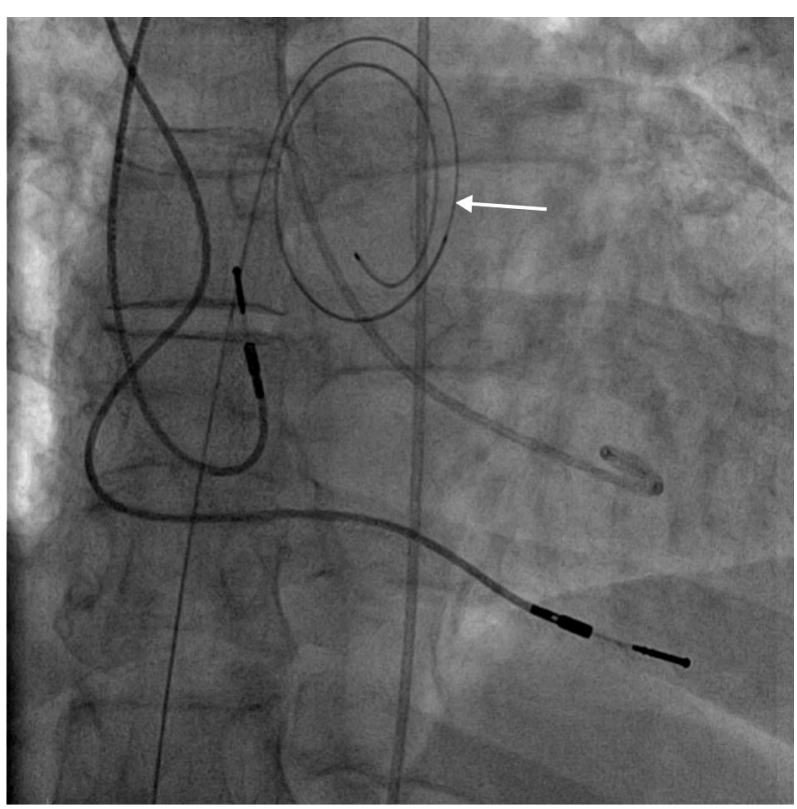

Ryc. 3. Prowadnik wprowadzony do lewego przedsionka (strzałka)

Fig. 3. Guidewire in the left atrium (arrow)

\section{Omówienie}

Przeprowadzone badania wykazały, że przezskórna komisurotomia mitralna jest metodą skuteczną i bezpieczną, dającą bardzo dobre wyniki bezpośrednie i odległe $u$ wybranych chorych ze zwężeniem zastawki dwudzielnej [1-6]. Należy jednak podkreślić, że jest to również jedna z trudniejszych metod leczenia stosowanych w kardiologii interwencyjnej, dlatego powinna być wykonywana tylko w ośrodkach o dużym doświadczeniu. Jeśli zabieg wykonuje doświadczony zespót, to częstość powikłań nie jest wysoka [2, 7]. W omawianym przypadku dodatkowe utrudnienie na każdym etapie procedury stanowiła obecność dwóch elektrod w jamie prawego przedsionka. Przy wykonywaniu komisurotomii przezskórnej przez prawy przedsionek przeprowadza się najpierw cewnik diagnostyczny Cournanda, następnie igłę do nakłucia przegrody międzyprzedsionkowej, a na końcu balon Inoue. Nieumiejętne manewrowanie każdym z tych urządzeń mogło spowodować przemieszczenie jednej lub obu elektrod i zaburzenia stymulacji serca. Szczególnej uwagi wymagało usunięcie cewnika Inoue po wysuniętym poza cewnik prowadniku. Prowadnik mający kształt pętli może się łatwo owinąć dookoła elektrody.

Jednym z trudniejszych elementów zabiegu jest nakłucie przegrody międzyprzedsionkowej, którego nieumiejętne wykonanie może spowodować tamponadę serca. Obecność elektrod w przedsionku utrudnia nakłucie przegrody międzyprzedsionkowej i zwiększa ryzyko spowodowania tamponady serca.

Nasze dotychczasowe doświadczenia w wykonywaniu przezskórnej komisurotomii mitralnej u chorych po

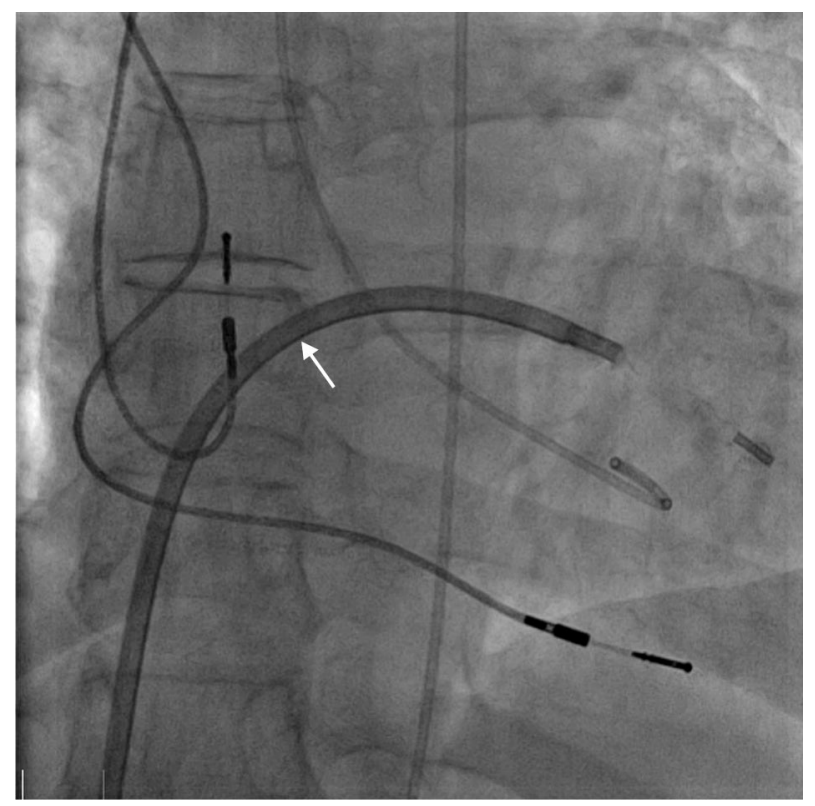

Ryc. 4. Cewnik Inoue w lewej komorze (strzałka) Fig. 4. Inoue catheter in the left ventricle (arrow)

wszczepieniu układu stymulującego są niewielkie. Przeprowadziliśmy kilka zabiegów w tej grupie chorych, ale wszystkie u pacjentów tylko z jedną elektrodą w prawym przedsionku. Dlatego ustalając dalsze postępowanie terapeutyczne w opisywanym przypadku, z uwagi na ryzyko przemieszczenia jednej lub obu elektrod, rozważaliśmy również leczenie operacyjne. Za leczeniem metodą nieoperacyjną przemawiał jednak stosunkowo młody wiek pacjentki, umiarkowane zmiany zastawki i aparatu podzastawkowego oraz współistniejąca nieistotna hemodynamicznie wada zastawki aortalnej. Istnieje duże prawdopodobieństwo, że w przyszłości wada zastawki aortalnej ulegnie nasileniu i chora będzie wymagała leczenia operacyjnego.

\section{Podsumowanie}

Opisany przypadek pokazuje, że zabieg przezskórnej komisurotomii mitralnej można wykonać bezpiecznie również u chorych z dwoma elektrodami w prawym przedsionku. Należy jednak pamiętać, że w takich przypadkach w trakcie zabiegu może nastąpić przemieszczenie elektrody i w efekcie mogą się pojawić zaburzenia stymulacji serca. Tacy chorzy powinni być kierowani do ośrodka o dużym doświadczeniu w wykonywaniu przezskórnej komisurotomii mitralnej.

\section{Piśmiennictwo}

1. Dean LS, Mickel M, Bonan R i wsp. Four-year follow-up of patients undergoing percutaneous balloon mitral commissurotomy. A report from the National Heart, Lung, and Blood Institute Balloon Valvuloplasty Registry. J Am Coll Cardiol 1996; 28: 1452. 
2. Iung B, Cormier B, Ducimetiere P i wsp. Immediate results of percutaneous mitral commissurotomy. Circulation 1996; 94 2124-2130.

3. Hernandez R, Banuelos C, Alfonso F i wsp. Long-term clinical and echocardiographic follow-up after percutaneous mitral valvuloplasty with the Inoue balloon. Circulation 1999; 99: 1580-1586.

4. lung B, Garbarz E, Michaud P i wsp. Immediate and mid-term results of repeat percutaneous mitral commissurotomy for restenosis following earlier percutaneous mitral commissurotomy. Eur Heart 2000; 21: 1683-1689.
5. Fawzy ME, Hegazy H, Shoukri M i wsp. Long term clinical and echocardiographic results after successful mitral balloon valvotomy and predictors of long-term outcome. Eur Heart J 2005; 26: 16471652.

6. Chmielak Z, Karcz M, Kruk M i wsp. Dwudziestoletnie doświadczenia w wykonywaniu przezskórnej komisurotomii mitralnej. Post Kardiol Interw 2008; 4, 3: 89-96.

7. Herrmann HC, Lima JAC, Feldman T i wsp. Mechanisms and outcome of severe mitral regurgitation after Inoue balloon valvuloplasty. J Am Coll Cardiol 1993; 27: 783-789. 